https://doi.org/10.18485/kud_kiaz.2019.ch52

Nigar Sultanova

Head of International Relations Department of Azerbaijan

University of Languages

\title{
EU -AZERBAIJAN: RENEWED DIALOGUE AND FUTURE PERSPECTIVES
}

\section{SUMMARY}

Today, we witness an intensification of bilateral relations between the EU and Azerbaijan. The European Union supports the territorial integrity of its neighbors, which is reflected in its different official documents. The visionary multi-vector and independent foreign policy of Azerbaijan has yielded positive results and today Azerbaijan is an equal partner of the EU. Partnership with the European Union is one of the main priorities of Azerbaijan's foreign policy and a new broad strategic agreement, which is to besigned in the near future, will open even greater perspectives for this partnership.

Key words: European Union, energy policy, Nagrno-Karabakh, Strategic Partnership Agreement.

\section{Introduction}

Since the establishment of EU-Azerbaijan relations their cooperation in different areas is gradually expanding. Today we witness growing dialogue between EU and Azerbaijan, notably the visits of President of Azerbaijan Ilham Aliyev to Brussels in November 2017 and February 2018. This article examines the current situation of these relations in the context of an intensification of EU-Azerbaijan relations and in light of negotiations on a new bilateral agreement launched in 2017. 
On 7 February 2017 following a visit by President Ilham Aliyev to Brussels, the European Union and Azerbaijan have launched negotiations on a new comprehensive agreement in order to modernise and revitalise the EU-Azerbaijan partnership. At present, bilateral EU-Azerbaijan relations are regulated by the partnership and cooperation agreement signed in 1996 and entered into force in 1999.

Azerbaijan is cooperating with European countries in various fields and it has signed a strategic partnership agreement with many member states of the European Union which also affects the development of the AzerbaijanEuropean relations.

The new agreement will better take into account shared objectives and challenges the EU and Azerbaijan face today. It is aimed atbroader partnership and the approximation of Azerbaijan's legislation and procedures to the EU standards in various areas.Azerbaijan-EU talks are conducted in three blocks: political and security; trade and investment; and economic, social and humanitarian issues.(En.apa.az, 2018)

Today, to the contrast of tense relations with the Council of Europe (Trend.Az, 2018)there is a positive and constructive development inEU-Azerbaijan cooperationin such areas as political, economic, security, cultural, trade and energy security, etc. These relations with an initial focus on humanitarian and financial assistance have transformed into a strong and broad partnership of mutual benefit.

Foundations of a balanced and independent foreign policy of Azerbaijanwere laid by national leader Heydar Aliyev. President Ilham Aliyev has continued this visionary strategyand independent course that correspond to national interests of the country. Presently, Azerbaijanis developing dynamically in all areas, and its international prominence is ever growing. Unfortuanetely, the stability and security in the region and beyond are disturbed by the conflict between Armenia and Azerbaijan which despite the consistent effortsofthe mediators remains unresolved until today. 
Azerbaijan is an important partner for the European Union that supports its independence, sovereignty and territorial integrity and considers the status-quo in the ArmeniaAzerbaijan Nagorno-Karabakh conflict unsustainable. In relation to the conflict between Armenia and Azerbaijan the EU fully supports the Organisation for Security and Cooperation in Europe (OSCE) Minsk Group Co-Chairs and confidence/peace building and conflict prevention activities. In generlEU's stance with reference to conflicts in Eastern Europe is the one of the strong support at all levels to the souverenity and territorial integrity of countries.

The EU provides a representation on the conflict through its Special Representative to the South Caucasus and the crisis in Georgia. EU Special Representatives promote the EU's policies and interests in certain regions playing an active role in efforts to consolidate peace, stability and the rule of law. There is also the European Partnership for the Peaceful Settlement of the Conflict over Nagorno-Karabakh (EPNK). It is an EUinitiative that seeks to positively impact the Nagorno-Karabakh conflict settlement process by promoting confidence/peacebuilding activities. (Epnk.org, 2018)

Unfortunately, EU approach to the conflicts sometimes goes through prism of double-standards. For instancethe approach of EU delegation to the OSCE regarding the Nagorno-Karabakh conflict was criticized by Azerbaijan. When addressing the $1169^{\text {th }}$ special meeting of the OSCE Permanent Council, in response to Mr. Johannes Hahn, the European Commissioner for European Neighborhood Policy and Enlargement Negotiations Azerbaijan announced its concern about the fact that EU senior officials avoid reiterating their position in support of sovereignty, territorial integrity and independence of Azerbaijan.(Trend.Az, 2018)

In general, the EU tries to have a balanced approach with respect to the conflict and confirmed it is readiness to take on a much bigger role in the period after a solution is agreed in post-conflict reconstruction and including restoration of communications. 
There was a period of crisis in relations between the parliament of Azerbaijan and the European Parliament. In 2015 Azerbaijani parliament's resolution stated about the termination of cooperation with the European Parliament after the latter adopted a biased and inadequate resolution against Azerbaijan.An illegal visitto the occupied territories of Azerbaijanterritory by Swedish MEP Lars Adaktusson in January 2018 also set back relations. (AzerNews.az, 2018)

Fortunately, today we see these relations reviving. On 15 November 2018, the European Parliament adopted Resolution on Eastern Partnership on foreign policy and security that clearly supports sovereignty and territorial integrity of the EU's eastern partners. (Europarl.europa.eu, 2018) Earlier in 2016 Global strategy for the European Unions's Foreign and Security Policy also supported territorial integrity of EU members and its neighbours:

The sovereignty, independence and territorial integrity of states, the inviolability of borders and the peaceful settlement of disputes are key elements of the European security order. These principles apply to all states, both within and beyond the EU's borders. (Europarl.europa.eu, 2016)

The EU is the largest economic partner of Azerbaijan with $48.6 \%$ of its total trade and providing the largest share of foreign direct investment. The majority of investments has been in the fields of energy, transport, and trade. More than 1500 companies from EU member states currently operate in Azerbaijan. These relations are regulated by the Partnership and Cooperation Agreement which is a nonpreferential agreement. It is aimed at strengthening business links, developing market-based rules and practices for trade in goods and services and gradual approximationof Azerbaijan's trade-related legislation with the EU and international laws and standards.

Energy policy of Azerbaijan shaped by the National Leader Heydar Aliyev and further enhanced by President Ilham Aliyev is aimed at prioritizing its own national interests. 
Due to this policy Azerbaijan maintained one of the leading roles in various regional and global projects and also became a reliable partner of European countries.

Azerbaijan isanimportant energy partnerfor the EU and it provides around 5\% of the EU's oil demand and plays a crucial role in bringing Caspian gas resources to the EU markets through the Southern Gas Corridor.

The above-mentioned frozen relations due to the resolution of the European Parliament affected the trade relations as well. Only in 2016 the negotiations on Special Partnership Agreement with Azerbaijan were resumed. The ambitious Southern Gas Corridor (SGC) project is a vivid example of cooperation of mutual interest of Azerbaijan and the EU.

Initiated by Joint Declaration on the Southern Gas Corridorthis projectenvisages to bring Caspian, Central Asian and Middle Eastern gas resources to the European markets. (Ec.europa.eu, 2018)

The SGC project has received a substantial financial support for the Trans-Adriatic Pipeline (TAP)as well as for Trans Anatolian Natural Gas Pipeline (TANAP) in order to be able to finalisethe construction in the nearest future. This is strategically important to diversify the EU's supply routes and cover Europe's growing need for gas.

Memorandum of Understanding on a Strategic Partnership between the Republic of Azerbaijan and the European Union in the Field of Energy signed in 2006 identified 4 priority areas of cooperation:

- Gradual harmonisation of Azerbaijani legislation with the Community legislation in the energy field leading to the convergence of the electricity and gas markets

- Enhancing the safety and security of energy supplies and transit systems from Azerbaijan and Caspian basin to the EU

- Development of a comprehensive energy demand management policy

- Technical Cooperation and the exchange of expertise(Europarl.europa.eu, 2018) 
One of the strategic objectives of Azerbaijan in the framework of sustainable development goals (SDGs) national priorities is to become one of the leading trade and logistics hubs of Eurasia by developing its transit and transport services. For this the country is actively engaged in implementing the major transportation projects such as the Baku-Tbilisi-Kars (BTK) railway and Baku International Sea Trade Port.

Baku International Sea Trade Port is a key strategic project in the diversification of economy of Azerbajan. In march 2018 the Baku International Sea Trade Port and the European Union presented a joint project entitled "EU support for the expansion of the operational capabilities of the new Baku port in Alat" which will cover 2018-2019. (Eurasia Diary, 2018) The project envisages an exchange of experience in the areas of port operations, management, business, human resources, labor and environmental protection, and public relations. The new port will serve as a transport and cargo station for the BTK railroad.

BTK railroad was inaugurated in 2017 enhancing hence the transport dimension of relations between EU and Azerbaijan. Not only the BTK railroad will ensure the interconnections of the Asian and European transport networks, but will also contribute to further development of the Europe-CaucasusAsia Transport Corridor (TRACECA) project.

Another example of cooperation in the field of transportis on-going negotiations on a Common Aviation Area Agreement. Once these negotiations are finished it will lead to a more efficient connectivity between Azerbaijan and the countries of the EU and augmenting mutual tourism. Creation of a common aviation area is an initiative of the European Commission and it aims to open and integrate aviation markets. This will consequently lead to new opportunities for consumers and operators, and, most importantly, to high standards in terms of flight safety as well as air traffic management.

Ensuring free movement of citizens around Europe in a secure environment is a key component of the Eastern 
Partnership. Based on this component the EU, a number of EU Member States, and Azerbaijan signed a Mobility Partnership in December 2013. Mobility, migration and asylum issuesas well as issues managing the return of irregular migrants are regulated by Visa Facilitation Agreementand the Readmission Agreement, which both entered into force on 1 September 2014. (Ec.europa.eu, 2018)

Azerbaijan has always been committed to the promotion of multiculturalism and religious tolerance. In December 2016 an International Conference on "Inter-religious tolerance and the role of media" was held in Baku. Next year leaders from various religious communities in Azerbaijan visited Brussels. Also, Baku hosted two "Imagine Euro Tolerance Festival"aimed at developing universal values uniting people. (EEAS - European External Action Service, 2018)

The European Union attaches special importance to the education system in Azerbaijan. Azerbaiajn carried out reforms to renew the content of education and to integrate its education into the European education system. The country joined the EU's education programmes in 1994.

Along with the unification of education standards and deepening of the Bologna Process, Azerbaijan is paying an increased attention to the expansion of the international relations of Azerbaijani institutions of higher education. In this this context worth mentioning that in 2014 several main EU programmes such as Tempus, Erasmus Mundus, Jean Monnet and others, were united under the single programme Erasmus ${ }^{+}$. Thisprogramme supports higher education institutions in Azerbaijan by funding academic mobilityof Azerbaijani students or short-term mobility of academic staff in a host institution in Europe. Also Erasmus+ contributes tocapacity buildingfor the modernisation and development of higher education. Jean Monnet programme promotes excellence in teaching and research in the field of EU studies for Azerbaijani institutions. EU high-level scholarships, joint master and doctoral degrees and youthactivities also 
contribute to the developing of bilateral relations between EU and Azerbaijan in the area of Education.

Together with projects aimed at development of higher education EU cooperates with Azerbaijan in order to improve vocational education and training. EU has extensive experience in this field. Numerous projects on development of vocational education in Azerbaijan funded by the EU, show the great importance that the EU attaches to the educational system of the country. (Azertag.az, 2018)

\section{Conclusion}

Today we witness an expansion in bilateral ties between Azerbaijan and the EU, two reliable and strategic partners. The new comprehensive agreement to be signed between Azerbaijan and the EU will replace the Partnership and Cooperation Agreement and it will sybolise a new impetus in the development of relations. Azerbaijan has a good record of cooperation with the EU in general and its member-states in particular. With regards to the Armenian-Azerbaijan NagornoKarabakh conflict that constitutes the key threat to security in the region, the EU recognises the territorial integrity of Azerbaijan. EU prioritizes maintaining stability and creating favorable conditions for the implementation of transport and energy projects in the South Caucasus region.

\section{Bibliography}

AzerNews.az. (2018). Azerbaijan makes statement on European Parliament's member visit to occupied lands [UPDATE]. [online] Available at: https://www.azernews.az/karabakh/126226.html [Accessed 25 May 2018].

Azertag.az. (2018). EU, UNDP extend support for vocational education development in Azerbaijan. [online] Available at: https:// azertag.az/en/xeber/EU_UNDP_extend_support_for_vocational_ education_development_in_Azerbaijan-1166140 [Accessed 26 May 2018]. 
Europarl.europa.eu. (2016). A Global Strategy for the European Union's Foreign And Security Policy - Eeas.europa.eu. (2018). [online] Available at: http://eeas.europa.eu/archives/docs/top_stories/pdf/eugs review_web.pdf [Accessed 15 May 2018].

Ec.europa.eu. (2018). [online] Action Document for "Support to new Mobility partnerships with Azerbaijan, Jordan and Tunisia Available at: https://ec.europa.eu/europeaid/sites/devco/files/aap_gpgc_ migration_and_asylum_c_2014_7585_action_fiche1_20141022_en.pdf [Accessed 26 May 2018].

Ec.europa.eu. (2018). Joint Declaration on the Southern Gas Corridor [online] Available at: https://ec.europa.eu/energy/sites/ener/ files/Joint_Declaration_Baku_2016.pdf [Accessed 25 May 2018].

European External Action Service EEAS - European External Action Service. (2018). IMAGINE Euro Tolerance Festival - EEAS European External Action Service - European Commission. [online] Available at: https://eeas.europa.eu/delegations/azerbaijan/33722/ imagine-euro-tolerance-festival_en [Accessed 25May. 2018].

En.apa.az. (2018). Details emerge of preliminary talks on Azerbaijan-EU agreement. [online] Available at: http://en.apa.az/ azerbaijan-politics/foreign-news/details-emerge-of-preliminary-talkson-azerbaijan-eu-agreement.html [Accessed 27 May 2018].

Europarl.europa.eu. Memorandum of Understanding on a Strategic Partnership between the Republic of Azerbaijan and the European Union in the Field of Energy (2018). [online] Available at: http://www.europarl.europa.eu/meetdocs/2009_2014/documents/dsca/ dv/dsca_20130321_14/dsca_20130321_14en.pdf [Accessed 25 May 2018].

Europarl.europa.eu. (2018).- Review of the European Neighbourhood Policy - Eastern Dimension - P7_TA(2011)0153. [online] Available at: http://www.europarl.europa.eu/sides/getDoc. do?type $=$ TA\&reference=P7-TA-2 Epnk.org. (2018). Homepage EPNK. [online] Available at: http://www.epnk.org [Accessed 24 May 2018].011-0153\&language $=$ EN [Accessed 15 May 2018] .

Eurasia Diary. (2018). EU Support to the Enhancement of the Operational Capabilities of the New Port of Baku \& Free Trade Zone at Alyat | Eurasia Diary. [online] Available at: http://ednews.net/ en/news/economy/258863-eu-support-to-the-enhancement-of-theoperational-capabilities-of-the-new-port-of-baku-free-trade-zone-atalyat [Accessed 26 May 2018].

Sizinavropa.az. «Imagine Euro Tolerance Festival» (2018). [online] Available at: https://sizinavropa.az/imagine [Accessed 25 May 2018]. 
Trend.Az. (2018). Azerbaijan criticizes double-standard approach by EU delegation to OSCE regarding Nagorno-Karabakh conflict. [online] Available at: https://en.trend.az/azerbaijan/2837307.html [Accessed 24 May 2018].

Trend.Az. (2018). Novruz Mammadov: Azerbaijani public concerned over unfair attitude of certain circles in West (UPDATE). [online] Available at: https://en.trend.az/azerbaijan/politics/2832339. html [Accessed 15 May 2018].

\section{PЕЗЮME}

Сегодня наблюдается интесификация двусторонних отношений между ЕС и Азербайджном. Европейский Союз поддерживает территориальную целостность своих соседей, что нашло свое отражение в ряде официальных документов ЕС. Дальновидная многовекторная и независимая внешняя политика Азербайджана дала свои положительные результаты и сегодня Азербайджан является равноправным партнером ЕС. Партнерство с Европейским союзм является одним из главных приоритетов внешней политики Азербайджана и новоеобширное стратегическое соглашение,которое в ближайщем будущем должно быть подписано, откроет для этого партнерства еще большие перспективы.

Ключевый слова: Европейский Союз, энергетическая стратегия, Нагорный Карабах, Соглашение по стратегическому Партнерству. 